\title{
Sessile drop study of Gd-Ti monotectic alloys on ceramic substrates: phase transformations, wetting, and reactivity
}

\author{
I. Kaban $\cdot$ R. Nowak $\cdot$ O. Shuleshova $\cdot$ B. Korpala $\cdot$ \\ G. Bruzda $\cdot$ A. Siewiorek $\cdot$ J. H. Han $\cdot$ N. Sobczak $\cdot$ \\ N. Mattern $\cdot$ J. Eckert
}

Received: 25 April 2012/Accepted: 25 July 2012/Published online: 17 August 2012

(C) The Author(s) 2012. This article is published with open access at Springerlink.com

\begin{abstract}
Gd-Ti monotectic alloys were studied in a wide temperature range by the sessile drop technique. The eutectic and monotectic transformations in $\mathrm{Gd}-\mathrm{Ti}$ alloys upon heating were in situ monitored by a high-speed and high-resolution CCD camera. Our findings suggest that the existing Gd-Ti phase diagram significantly underestimates the monotectic and binodal temperatures in this system. The wetting behavior and the high-temperature interaction of the Gd-Ti melts with yttria and yttria-stabilized zirconia substrates were investigated.
\end{abstract}

\section{Introduction}

According to the equilibrium phase diagram [1], the Gd-Ti system exhibits a miscibility gap in the liquid state. This makes Gd-Ti-based multicomponent alloys appropriate for fabrication of nano- and microphase-separated composite materials. Such composites have a high application potential due to combination of two or more phases with remarkably different properties. The microstructure of solid alloys that exhibit a liquid-liquid miscibility gap is determined by their thermophysical properties and casting

I. Kaban · O. Shuleshova · J. H. Han · N. Mattern · J. Eckert Institute for Complex Materials, IFW Dresden,

P.O. Box 270116, 01171 Dresden, Germany

R. Nowak $(\bowtie) \cdot$ B. Korpala · G. Bruzda · A. Siewiorek ·

N. Sobczak

Center for High Temperature Studies, Foundry Research

Institute, Zakopianska Str. 73, 30-418 Kraków, Poland

e-mail: rnowak@iod.krakow.pl

J. Eckert

Institute of Materials Science, TU Dresden, 01062 Dresden,

Germany conditions (see, for example, refs. [2-8] and citations therein). The Gd-Ti system also plays an important role in the synthesis of high-performance alloys for magnetic applications by alloying, for example, with $\mathrm{Ge}, \mathrm{Mn}, \mathrm{Fe}$, and Sn [9-12]. These materials are usually produced by melting of pure components and subsequent homogenization of the melts at certain temperatures determined from the respective phase diagrams. Therefore, knowledge of thermodynamic and thermophysical properties of the molten alloys is of high practical importance. In this context, accurate data on the binary systems are indispensable.

In this work, we investigated binary $\mathrm{Gd}-\mathrm{Ti}$ alloys upon heating by the sessile drop technique. Due to the use of a high-speed and high-resolution charge-coupled device (CCD) camera, it was possible to record the wetting behavior and the high-temperature interaction of the $\mathrm{Gd}-$ Ti melts with yttria and yttria-stabilized zirconia substrates. Moreover, this technique allowed real-time observation of the eutectic and monotectic phase transformations in the Gd-Ti alloys. The microstructure of solidified $\mathrm{Gd}-\mathrm{Ti}$ bulk samples as well as the interfaces formed in the sessile drop investigations between $\mathrm{Gd}-\mathrm{Ti}$ alloys and ceramics were characterized by scanning electron microscopy (SEM) combined with energy-dispersive $\mathrm{X}$-ray (EDX) spectrometry.

\section{Experimental procedures}

$\mathrm{Gd}_{40} \mathrm{Ti}_{60}$ and $\mathrm{Gd}_{60} \mathrm{Ti}_{40}$ alloys were selected for the investigations. According to the $\mathrm{Gd}-\mathrm{Ti}$ phase diagram [1], both alloys fall into the liquid miscibility gap: $\mathrm{Gd}_{40} \mathrm{Ti}_{60}$-close to the monotectic composition $x_{\mathrm{M}}=35$ at. $\% \mathrm{Gd}$ and $\mathrm{Gd}_{60} \mathrm{Ti}_{40}$-close to the critical composition $x_{\mathrm{C}} \approx 63$ at.\% Gd (Fig. 1). Samples of nearly spherical shape with about 


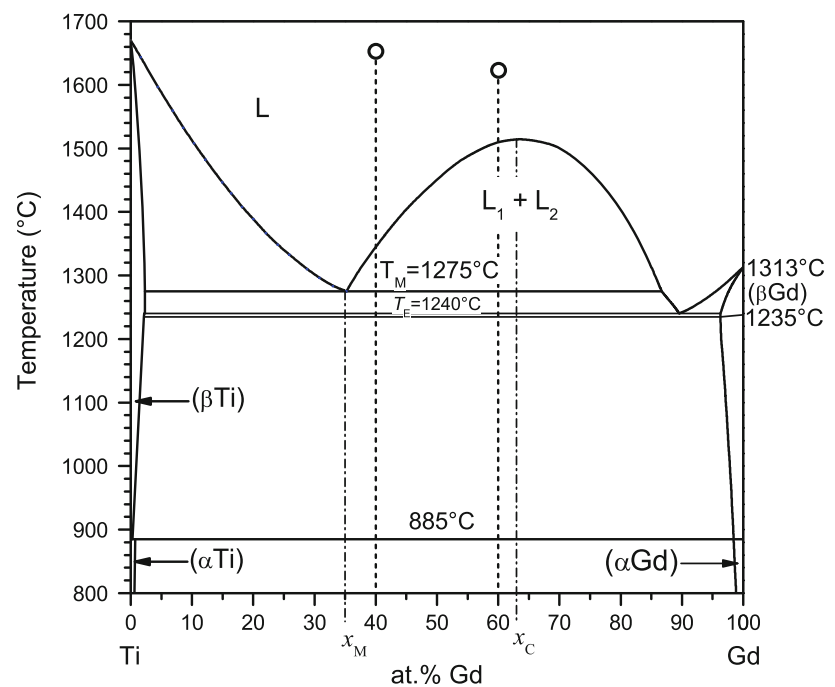

Fig. $1 \mathrm{Gd}-\mathrm{Ti}$ phase diagram [1]. Vertical dashed lines point to the compositions studied in this work; circles mark the maximum temperature achieved in the sessile drop experiments

$800 \mathrm{mg}$ mass were prepared by arc-melting of high purity elements (99.99\% or higher) under an argon atmosphere.

Polycrystalline yttria $\left(\mathrm{Y}_{2} \mathrm{O}_{3}\right)$ and two kinds of yttriastabilized zirconia $\left(\mathrm{ZrO}_{2}\right.$ stabilized with 3 wt. $\%$ of $\mathrm{Y}_{2} \mathrm{O}_{3} \equiv$ $3 \mathrm{YSZ}$ and $\mathrm{ZrO}_{2}$ stabilized with 5 wt. $\%$ of $\mathrm{Y}_{2} \mathrm{O}_{3} \equiv 5 \mathrm{YSZ}$ ) were used as substrates in the sessile drop experiments. The substrates were polished with the same oxide powder that was used for the sintering of the ceramics, to avoid their pollution.

The sessile drop investigations were carried out using the experimental setup described in details in ref. [13]. Before loading into the UHV chamber equipped with a vertical resistance heater, the $\mathrm{Gd}-\mathrm{Ti}$ samples and substrates were cleaned ultrasonically in isopropanol for $5 \mathrm{~min}$. Heating was started when the level of vacuum reached at least $10^{-6}$ mbar. At $500{ }^{\circ} \mathrm{C}$, high purity $\mathrm{Ar}(99.999 \%)$ was introduced into the chamber. The flow rate was $5 \mathrm{~cm}^{3} \mathrm{~min}^{-1}$ and the pressure level inside the high-temperature chamber was held in the range of $850-900$ mbar. The heating rate was $6 \mathrm{~K} \mathrm{~min}^{-1}$ and the cooling rate was $18 \mathrm{~K} \mathrm{~min}^{-1}$.
The behavior of the Gd-Ti samples on ceramic substrates was registered by a high-speed and high-resolution CCD camera. The experiments were performed from room temperature up to some degrees Kelvin above the point, where $\mathrm{Gd}-\mathrm{Ti}$ droplets looked as being completely melted. At the first stage of heating up to $1000{ }^{\circ} \mathrm{C}$, the drop image acquisition was $1 \mathrm{fps}$ (frame per sec), after that it was increased to $100 \mathrm{fps}$.

After cooling, the $\mathrm{Gd}-\mathrm{Ti} /$ substrate couples from the sessile drop experiments were cut in the central part perpendicular to the substrate surface and their microstructure and composition characterization was performed with Hitachi TM3000 SEM microscope equipped with an EDX analyzer.

\section{Results}

The first sessile drop tests with the $\mathrm{Gd}_{40} \mathrm{Ti}_{60}$ and $\mathrm{Gd}_{60} \mathrm{Ti}_{40}$ alloys were carried out using $\mathrm{Y}_{2} \mathrm{O}_{3}$ substrates. Incipient melting for both compositions was observed at about $1240-1250{ }^{\circ} \mathrm{C}$, when the Gd-rich liquid filled the gap between the sample and the substrate. The volume fraction of the liquid phase increased upon further heating. However, the alloys were not completely molten at $1275^{\circ} \mathrm{C}$, as predicted by the calculated phase diagram [1] (Fig. 1). A skeleton of the lighter Ti-rich solid phase was observed to "float" on the Gd-rich liquid. At $\sim 1350{ }^{\circ} \mathrm{C}$, the liquid phase began to wet the yttria substrate and at $\sim 1430{ }^{\circ} \mathrm{C}$ began to penetrate it. The heating was stopped at $1450-1460{ }^{\circ} \mathrm{C}$, when almost the whole substrate was penetrated by the Gd-rich liquid. For illustration of the described phenomenon, three images for the $\mathrm{Gd}_{60} \mathrm{Ti}_{40}$ composition taken during heating at 1370, 1410, and $1450{ }^{\circ} \mathrm{C}$, and an image of the $\mathrm{Gd}_{60} \mathrm{Ti}_{40} / \mathrm{Y}_{2} \mathrm{O}_{3}$ couple after the experiment are shown in Fig. 2. The same behavior has been observed for the $\mathrm{Gd}_{40} \mathrm{Ti}_{60}$ composition.

Due to infiltration of molten Gd-rich phase into $\mathrm{Y}_{2} \mathrm{O}_{3}$ as described above, $\mathrm{ZrO}_{2}$ stabilized with $\mathrm{Y}_{2} \mathrm{O}_{3}$ was chosen as an alternative substrate material. Still notable reaction
Fig. 2 a-c Images of the $\mathrm{Gd}_{60} \mathrm{Ti}_{40}$ alloy on $\mathrm{Y}_{2} \mathrm{O}_{3}$ substrate taken during heating in a sessile drop experiment; d image of the $\mathrm{Gd}_{60} \mathrm{Ti}_{40} / \mathrm{Y}_{2} \mathrm{O}_{3}$ couple after the hightemperature test. Gd-rich liquid wets the Ti-rich solid phase as well as the substrate. At $1450{ }^{\circ} \mathrm{C}$, all available Gd-rich liquid penetrates the substrate

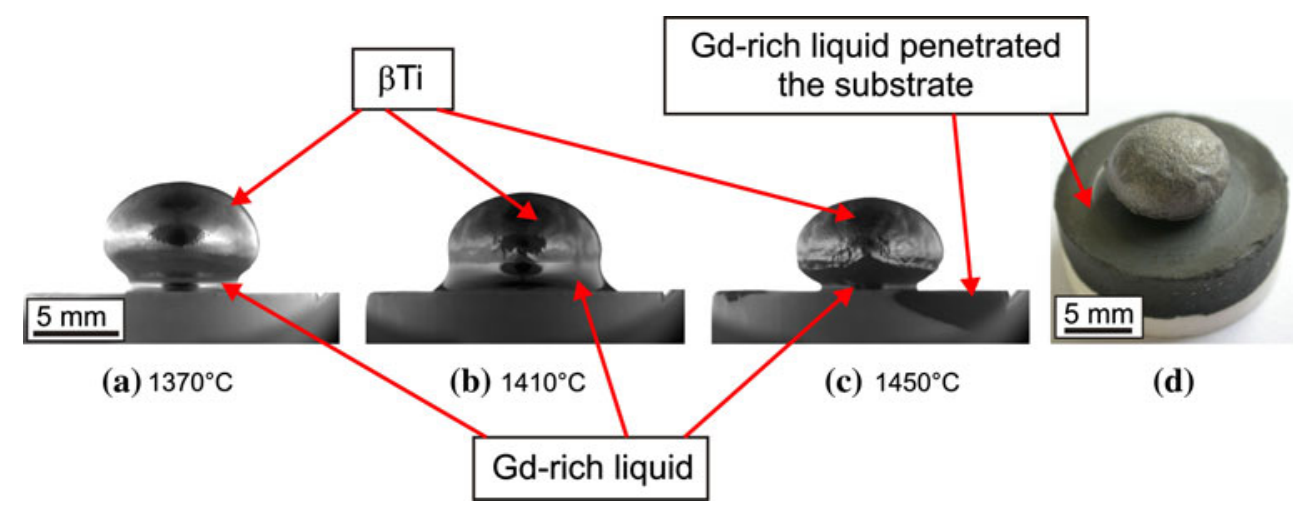




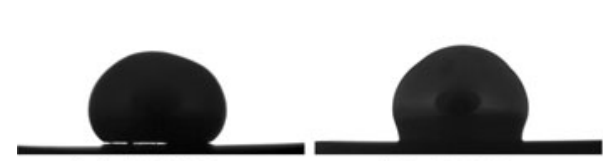

(a) $1232^{\circ} \mathrm{C}$

(b) $1350^{\circ} \mathrm{C}$

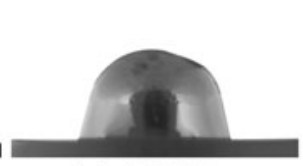

(c) $1600^{\circ} \mathrm{C}$

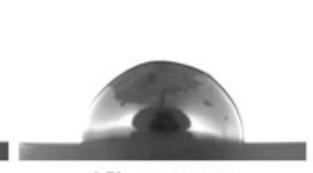

(d) $1650^{\circ} \mathrm{C}$

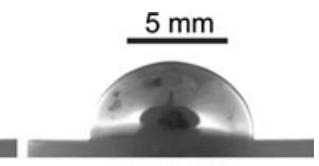

(e) $1654^{\circ} \mathrm{C}$

Fig. 3 Images of the $\mathrm{Gd}_{40} \mathrm{Ti}_{60}$ alloy on a $3 \mathrm{YSZ}$ substrate taken at various temperatures. At about $1230{ }^{\circ} \mathrm{C}$, the sample starts melting; it is completely molten at $1654{ }^{\circ} \mathrm{C}$

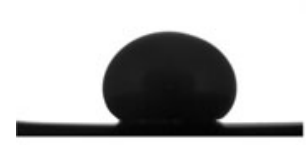

(a) $1222^{\circ} \mathrm{C}$

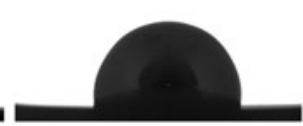

(b) $1350^{\circ} \mathrm{C}$

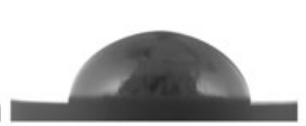

(c) $1600^{\circ} \mathrm{C}$

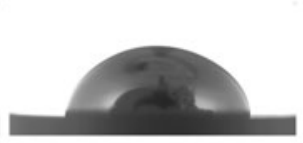

(d) $1620^{\circ} \mathrm{C}$

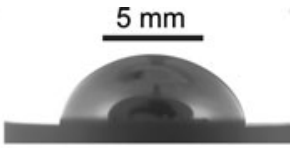

(e) $1624^{\circ} \mathrm{C}$

Fig. 4 Images of the $\mathrm{Gd}_{60} \mathrm{Ti}_{40}$ alloy on a $3 \mathrm{YSZ}$ substrate taken at various temperatures. The sample starts melting at about $1220{ }^{\circ} \mathrm{C}$; it is completely molten at about $1620{ }^{\circ} \mathrm{C}$

(a)
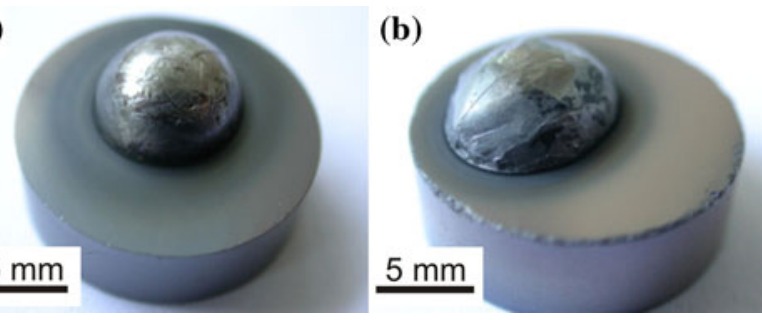

Fig. $5 \mathrm{Gd}_{40} \mathrm{Ti}_{60}(\mathbf{a})$ and $\mathrm{Gd}_{60} \mathrm{Ti}_{40}(\mathbf{b})$ alloys on 3 YSZ substrates after sessile drop investigations

between the Gd-Ti melts and ceramic was observed in the case of 5YSZ (not shown), while the substrates made of 3 YSZ were quite stable and resistant against molten Gd-Ti. Selected sessile drop images of the $\mathrm{Gd}_{40} \mathrm{Ti}_{60}$ and $\mathrm{Gd}_{60} \mathrm{Ti}_{40}$ alloys on the 3YSZ ceramics are shown in Figs. 3 and 4, respectively. Similar to the studies carried out on the $\mathrm{Y}_{2} \mathrm{O}_{3}$ substrates, melting of these compositions starts at about 1220-1230 ${ }^{\circ} \mathrm{C}$ (Figs. 3a, 4a). At $\sim 1370{ }^{\circ} \mathrm{C}$, the Gd-rich phase begins to wet $3 \mathrm{YSZ}$ substrate, but it does not penetrate the substrate. After the incipient melting, the shape of both $\mathrm{Gd}_{40} \mathrm{Ti}_{60}$ and $\mathrm{Gd}_{60} \mathrm{Ti}_{40}$ samples remains quite irregular over a wide temperature range: the bottom part of the semi-solid drop-heavier Gd-rich liquid phase-is rather symmetrical, while the upper part is asymmetrical due to the floating solid Ti-rich phase. The drops become axisymmetrical at $\sim 1620{ }^{\circ} \mathrm{C}$ for $\mathrm{Gd}_{60} \mathrm{Ti}_{40}$ and at $\sim 1654{ }^{\circ} \mathrm{C}$ for $\mathrm{Gd}_{40} \mathrm{Ti}_{60}$ indicating that the samples are completely molten.

Initially white, $\mathrm{ZrO}_{2}$ stabilized with 3 wt.\% $\quad \mathrm{Y}_{2} \mathrm{O}_{3}$ became light gray in the region surrounding $\mathrm{Gd}-\mathrm{Ti}$ drop after the high-temperature tests (Fig. 5); but unlike other substrates used in this study, there was no obvious penetration of the liquid phase into the 3YSZ (Fig. 6a, b). Instead, $\mathrm{GdZrO}$ crystals (up to about $10 \mu \mathrm{m}$ in length) were observed on the ceramic surface outside the Gd-Ti drop, as demonstrated in Fig. 6c.

\section{Discussion}

It is a challenge to find a suitable crucible or substrate material for high-temperature investigations of liquid alloys containing such highly reactive components as $\mathrm{Ti}$ and $\mathrm{Gd}$. $\mathrm{Y}_{2} \mathrm{O}_{3}$ was reported to be relatively stable against molten Ti [14]; although small quantities of Y and $\mathrm{O}$ could be dissolved from the ceramic $[14,15]$. On the other hand, liquid $\mathrm{Ti}$ and Ti-based alloys severely react with $\mathrm{Al}_{2} \mathrm{O}_{3}$ and $\mathrm{ZrO}_{2}$ ceramics $[16,17]$. Despite a lack of information on the interaction between liquid Gd and ceramics, a high chemical aggressivity of rare metals is known. Based on the literature data on reactivity of Ti-based alloys, the polycrystalline $\mathrm{Y}_{2} \mathrm{O}_{3}$ substrates were selected for our first sessile drop tests. However, they were quickly penetrated by the liquid Gd phase, as demonstrated in Fig. 2. This well-distinguished infiltration of the first liquid into $\mathrm{Y}_{2} \mathrm{O}_{3}$ enabled a visual observation of the two-phase state (Ti-rich solid and Gd-rich liquid) in the $\mathrm{Gd}-\mathrm{Ti}$ system at the temperatures between 1240 and $1460{ }^{\circ} \mathrm{C}$.

It should be noted that just a very small quantity of $\mathrm{Y}$ (0.1-0.3 at.\%) was found in the Ti-rich phase solidified on the yttria substrate. We suppose that $Y$ could have appeared there either due to a slight dissolution of the substrate during the sessile drop tests or during the cutting and subsequent polishing of the $\mathrm{Gd}-\mathrm{Ti} / \mathrm{Y}_{2} \mathrm{O}_{3}$ couples for the SEM/EDX characterization, or both.

The situation has been essentially changed in the case of yttria-stabilized zirconia. Neither Ti nor Gd was found in the drop-side region of the 3YSZ substrates after the sessile drop tests. Pollution of the Gd-Ti sample due to interaction with the $\mathrm{ZrO}_{2}$ substrate was very small (about $0.5-1$ at.\% 

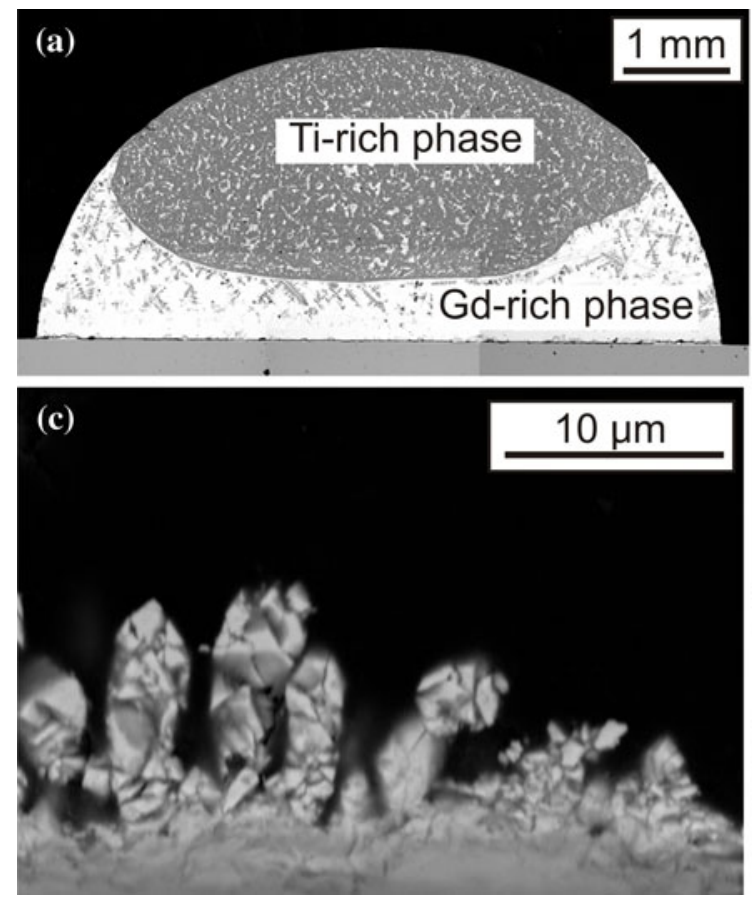

Fig. 6 SEM images of the cross section for the Gd-Ti samples on the 3 YSZ substrates after sessile drop investigations: a $\mathrm{Gd}_{40} \mathrm{Ti}_{60}$, b $\mathrm{Gd}_{60} \mathrm{Ti}_{40}$, c image taken at the outer edge of the $\mathrm{Gd}_{40} \mathrm{Ti}_{60}$ drop as marked by a rectangle in the panel $b$ : GdZrO crystals have grown on

$\mathrm{Zr}$ in some solidified drops was detected by EDX). It has been reported in ref. [18] that the high-temperature $\left(1400{ }^{\circ} \mathrm{C}\right)$ solid-state reaction and interdiffusion between yttria-stabilized zirconia and $\mathrm{GdCeO}$ is suppressed due to the formation of a thin $(\leq 1 \mu \mathrm{m})$ interaction zone. A similar phenomenon might occur at the contact of Gd-rich liquid and YSZ ceramic. It is plausible that a thin GdZrO layer is formed at the interface and prevents interdiffusion of components and further growth of the reaction zone. At the same time, Gd atoms may diffuse from the Gd liquid phase along the ceramic surface feeding the growth of $\mathrm{GdZrO}$ crystals in the vicinity of the drop, as observed in Fig. 6c. Obviously, GdZrO grows on the expense of $\mathrm{Zr}$ and $\mathrm{O}$ from the 3 YSZ substrate. The loss of oxygen resulting in the formation of a nonstoichiometric $\mathrm{ZrO}_{2-x}$ [19] could explain gray coloring of the substrates, noted during the high-temperature tests.

The melting temperature for the Gd-rich phase in the $\mathrm{Gd}_{40} \mathrm{Ti}_{60}$ and $\mathrm{Gd}_{60} \mathrm{Ti}_{40}$ alloys $\left(1220-1250{ }^{\circ} \mathrm{C}\right)$ determined upon heating in the present sessile drop studies on all substrates shows a good agreement with the eutectic isotherm $\left(T_{\mathrm{E}}=1240{ }^{\circ} \mathrm{C}\right)$ from the $\mathrm{Gd}-\mathrm{Ti}$ phase diagram [1]. However, the tests carried out on the $\mathrm{Y}_{2} \mathrm{O}_{3}$ substrates revealed that the monotectic temperature $\left(T_{\mathrm{M}}=1275^{\circ} \mathrm{C}\right)$ in the phase diagram (Fig. 1) is significantly underestimated. Indeed, the Ti-rich phase remained solid until $1450-1460{ }^{\circ} \mathrm{C}$ in those experiments. As it has been
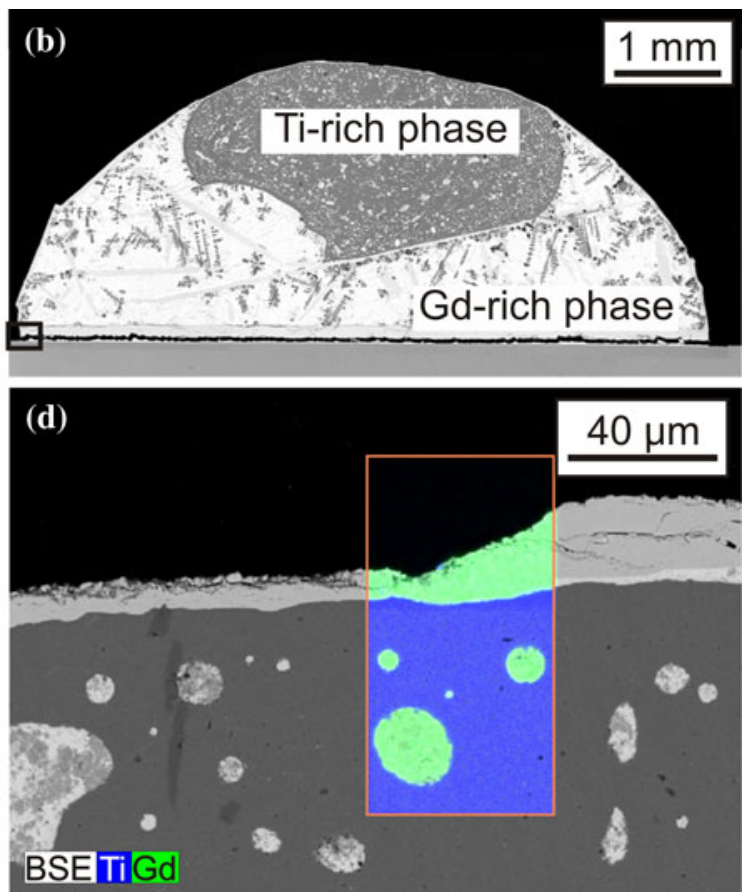

the substrate outside the sample/substrate contact zone, and $\mathbf{d}$ image taken at the top of the $\mathrm{Gd}_{60} \mathrm{Ti}_{40}$ sample: Ti-rich phase (dark) is covered by a thin layer of the Gd-rich phase (light)

established in the sessile drop measurements performed on the 3YSZ ceramics, the Ti-rich phase melts at about $1620-1650{ }^{\circ} \mathrm{C}$. Comparison of the images of the $\mathrm{Gd}_{40} \mathrm{Ti}_{60}$ and $\mathrm{Gd}_{60} \mathrm{Ti}_{40}$ sessile drops (Figs. 3e, 4d, e) with the experimental and calculated sessile drop profiles for the $\mathrm{Ga}-\mathrm{Pb}$ phase-separated melts studied close to the respective monotectic temperature in ref. [20] suggests that the $\mathrm{Gd}-\mathrm{Ti}$ alloys at $1620-1650{ }^{\circ} \mathrm{C}$ are rather in a two-phase liquid state than a single-phase liquid. The $\mathrm{Gd}_{40} \mathrm{Ti}_{60}$ and $\mathrm{Gd}_{60} \mathrm{Ti}_{40}$ samples after the sessile drop investigations on the 3YSZ substrates exhibit macroscopic phase separation (Fig. 6a, b). The oval-like shape of the Ti-rich phase, distorted during crystallization, and its location inside the Gdrich phase at the top of the samples also indicates that the alloys were completely molten and both fall into the miscibility gap.

The melting temperature for the Ti-rich phase following from our study is about $350-400 \mathrm{~K}$ above the calculated monotectic temperature [1] and about 190-240 K above the melting temperature reported in ref. [21]. Such a big difference cannot be an effect of the applied heating rate, which is rather moderate $\left(6 \mathrm{~K} \mathrm{~min}^{-1}\right)$, since the liquid phase is already present (recall that the Gd-rich phase melts at $1240{ }^{\circ} \mathrm{C}$ ). Also, the melting temperature of the Ti-rich phase is unlikely to be influenced by a very small quantity of either $\mathrm{Y}$ or $\mathrm{Zr}$ found mainly in the Gd-rich phase after the high-temperature tests. The large disagreement of the 
experimental results can be explained by the different techniques applied in the present work (sessile drop method) and in ref. [21] (thermal-gradient method [22]). The thermal-gradient method, in which melting is detected by optical observation of a cavity in the sample, is rather uncertain in two-phase melting alloys, as the cavity is usually filled by the first liquid or the specimen collapses before the second phase completely melts [23]. It should also be noted that the melting data reported in ref. [21] suffered large scattering and were severely reinterpreted during calculations [1]. Our findings suggest that the liquid state equilibria in the Gd-Ti phase diagram [1] should be reassessed.

The Ti-rich phase in the Gd-Ti samples solidified after the sessile drop measurements was completely covered by about 5-40 $\mu \mathrm{m}$ thick layer of the Gd-rich phase as it can be seen on the SEM/EDX image in Fig. 6d. Earlier, such surface wetting layers have been observed in other monotectic alloys; for example in $\mathrm{Ga}-\mathrm{Bi}$ [24], $\mathrm{Ga}-\mathrm{Pb}$ [25], $\mathrm{Cu}-\mathrm{Co}$ [26], and Al-In [27]. Calculations showed that complete wetting is preserved in many immiscible systems far below the monotectic or even eutectic temperature [27-29], and this has been related to the high surface tension $\sigma$ of metallic liquids. Bearing in mind that $\sigma$ of the liquid $\mathrm{Gd}$ is $\sim 800 \mathrm{mN} \mathrm{m}^{-1}$ at $1600{ }^{\circ} \mathrm{C}$ [30] and $\sigma$ of the liquid $\mathrm{Ti}$ is $\sim 1450 \mathrm{mN} \mathrm{m}^{-1}$ at $1700{ }^{\circ} \mathrm{C}$ [31], it is reasonable to suppose that the Gd-rich phase completely wets the Ti-rich phase in the liquid Gd-Ti alloys and the equilibrium wetting layer grows by diffusion up to a micrometer thickness during solidification as it has been suggested in ref. [27].

\section{Summary}

The sessile drop technique equipped with a high-speed and high-resolution CCD camera was used for in situ observation of the eutectic and monotectic phase transformations in the $\mathrm{Gd}-\mathrm{Ti}$ alloys as well as of the high-temperature interaction of the melts with yttria and yttria-stabilized zirconia substrates.

The observed eutectic transformation in the $\mathrm{Gd}_{40} \mathrm{Ti}_{60}$ and $\mathrm{Gd}_{60} \mathrm{Ti}_{40}$ alloys at about $1220-1250{ }^{\circ} \mathrm{C}$ is in a good agreement with the experimental [21] and calculated [1] Gd-Ti phase diagram. In contrast, the monotectic temperature determined by the analysis of the Gd-Ti sessile drop images taken by a high-speed/high-resolution CCD camera lies between 1620 and $1650{ }^{\circ} \mathrm{C}$, which significantly exceeds the monotectic temperature $\left(1275^{\circ} \mathrm{C}\right)$ calculated in ref. [1]. After the high-temperature tests, the surface of the Ti-rich phase in the solidified Gd-Ti samples is covered by a micrometer-thick layer of the Gd-rich phase suggesting that complete wetting in the $\mathrm{Gd}-\mathrm{Ti}$ system occurs in a wide temperature range above and below the monotectic temperature.

The Gd-rich liquid phase of the semi-solid $\mathrm{Gd}_{40} \mathrm{Ti}_{60}$ and $\mathrm{Gd}_{60} \mathrm{Ti}_{40}$ alloys wets $\mathrm{Y}_{2} \mathrm{O}_{3}$ at about $1350{ }^{\circ} \mathrm{C}$ and penetrates the ceramic at $1430-1450{ }^{\circ} \mathrm{C}$. The $\mathrm{Gd}-\mathrm{Ti}$ melt reacts relatively strongly with the $\mathrm{ZrO}_{2}$ substrates containing $5 \mathrm{wt} . \%$ $\mathrm{Y}_{2} \mathrm{O}_{3}$. The substrates made of the $\mathrm{ZrO}_{2}$ stabilized with 3 wt. $\% \mathrm{Y}_{2} \mathrm{O}_{3}$ are stable at contact with the $\mathrm{Gd}-\mathrm{Ti}$ melts over a wide temperature range up to about $1650{ }^{\circ} \mathrm{C}$.

Acknowledgements This study has been carried out in the frame of the German-Polish collaboration program between the German Academic Exchange Service DAAD (Project No. DAAD50755060) and the Ministry of Science and Higher Education of Poland (Project \#002/2011/2012). DAAD and the Foundry Research Institute in Cracow are acknowledged for the financial support.

Open Access This article is distributed under the terms of the Creative Commons Attribution License which permits any use, distribution, and reproduction in any medium, provided the original author(s) and the source are credited.

\section{References}

1. Massalski TB, Murray JL, Bennet KH, Baker H (1990) Binary alloy phase diagrams, 2nd edn. American Society for Metals, Metals Park, p 1935

2. Chattopadhyay K, Ramachandrarao P (1980) J Mater Sci 15:685. doi:10.1007/BF00551735

3. Prinz B, Romero A, Ratke L (1995) J Mater Sci 30:4715. doi: 10.1007/BF01153083

4. Fujii H, Kimura T, Kitaguchi H, Kumakura H, Togano K, Mohri M (1995) J Mater Sci 30:3429. doi:10.1007/BF00349890

5. Yang S, Liu W, Jia J (2001) J Mater Sci 36:5351. doi:10. 1023/A:1012467817033

6. Rathz TJ, Robinson MB, Li D, Workman GL, Williams G (2001) J Mater Sci 36:1183. doi:10.1023/A:1004885926618

7. Zhao J, Ratke L, Jia J, Li Q (2002) J Mater Sci Technol 18:197

8. Kaban I, Köhler M, Ratke L, Nowak R, Sobczak N, Mattern N, Eckert J, Greer AL, Sohn SW, Kim DH (2012) J Mater Sci. doi: 10.1007/s10853-012-6660-3

9. Morozkin AV (1999) J Alloy Compd 287:185

10. Jingqi L, Jiqin Q, Ren D, Yinghong Z, Jinli H (2006) J Alloy Compd 414:97

11. Ma J, Zhan Y, Zhang G, Guo Q, Du Y, He Y (2009) J Alloy Compd 485:196

12. Ma J, Zhan Y, She J, Yang Z, Liang J (2010) J Alloy Compd 489:384

13. Sobczak N, Nowak R, Radziwill W, Budzioch J, Glenz A (2008) Mater Sci Eng A 495:43

14. Helferich RL, Zanis CA (1973) Naval Ship Research and Development Center, Rep. 28-409, Annapolis, MD

15. Naidich YV (1981) Progress in surface and membrane science, vol 14. Academic Press, New York, p 353

16. Nowak R, Lanata T, Sobczak N, Ricci E, Giuranno D, Novakovic R, Holland-Moritz D, Egry I (2010) J Mater Sci 45:1993. doi: 10.1007/s10853-009-4061-z

17. Lin KF, Lin CC (1998) Scr Mater 39:1333

18. Tsoga A, Gupta A, Naoumidis A, Nikolopoulos P (2000) Acta Mater 48:4709 
19. Gladkov VE, Berezin VM, Zhekhanova NB (2010) Inorg Mater 46:754

20. Chatain D, Wynblatt P, de Ruijter M, de Conninck J, Carter C (1999) Acta Mater 47:3049

21. Croeni JG, Rhoads SC, Armantrout CE, Kato H (1961) U.S. Bureau of Mines, Rep. Invest. 5796, Washington, DC

22. Pirani M, Alterthum H (1923) Z Elektrochem 29:5

23. Rudy E, Progulski J (1967) Planseeber Pulvermetall 15:13

24. Perepezko JH, Galaup C, Cooper KP (1982) Mater Res Soc Symp Proc 9:491

25. Calmes C, Giuranno D, Chatain D (2009) J Mater Sci 44:5949. doi:10.1007/s10853-009-3563-z
26. Curiotto S, Battezzati L, Johnson E, Pryds N (2007) Acta Mater 55:642

27. Kaban I, Curiotto S, Chatain D, Hoyer W (2010) Acta Mater 58:3406

28. Chatain D, Eustathopoulos N, Desre P (1984) J Colloid Interface Sci 83:384

29. Wynblatt P, Saul A, Chatain D (1998) Acta Mater 46:2337

30. Ichikawa T, Okada JT, Paradis PF, Watanabe Y (2010) Int J Thermophys 31:288

31. Zhu J, Kamiya A, Yamada T, Shi W, Naganuma K, Mukai K (2002) Mater Sci Eng A 327:117 